\title{
OVERCOMING MALNUTRITION PROBLEM BY INCREASING NUTRITIONAL AWARENESS IN DESA PAGEDANGAN
}

\author{
Maria D.P.T. Gunawan Puteri ${ }^{*}$, Stacia A. Fortunata ${ }^{1}$ Laurensia Christli $^{1}$,Tabligh Permana ${ }^{1}$, \\ Filiana Santoso ${ }^{1}$ \\ ${ }^{1}$ Food Technology Department, Swiss German University, Tangerang, 15143 \\ *Corresponding author: maria.gunawanputeri@sgu.ac.id
}

\begin{abstract}
Children malnutrition is a crucial problem in developing countries including Indonesia. The root main cause of malnutrition is due to the lack of educational background and low economical condition, resulting in inadequate protein intake that still below the Recommended Dietary Allowance (RDA). It was recorded that $6.89 \%$ of children under five years old suffered from malnutrition in Desa Pagedangan, Tangerang Selatan. To overcome this problem, community service was conducted to increase nutritional awareness and fulfill the adequate amount of protein in daily basis. The community service covered seminars, cooking demo, and product development of healthy food. The seminar aimed to introduce the importance and benefit of healthy diet to parents, while cooking demo aimed to give ideas and encourage parents to prepare healthy diet. Some questionnaires were distributed after seminars and cooking demo to get the feedback from participant. The results showed both cooking demo and seminars were giving beneficial contribution for participant (100\% were agree). The formulation of rice porridge with overripe tempe was conducted aimed to fulfill the RDI of protein with preferable sensory acceptance. The final product showed better sensory acceptance than commercial product with mean value $6.47 \pm 0.73$ for overall acceptance by hedonic taste. The total protein content per serving able to fulfill 4.5/18 RDI of infants 7-11 months old.
\end{abstract}

Keywords : malnutrition, overripe tempe, protein, children

\section{INTRODUCTION}

Malnutrition especially for children is a concerning problem in Indonesia. Based on Badan Penelitian dan Pengembangan Kesehatan Kementerian Kesehatan RI (2016), the prevalence of underweight children under 5 years fluctuated from $18.4 \%$ in 2007 to $17.9 \%$ in 2010 but then increased to $19.6 \%$ in 2013. Between 2010 and 2013 , numbers of stunting increased from $35.6 \%$ to $37.2 \%$ or equal to 8.4 million children. Even though the number of stunting in 2016 decreased to $27.5 \%$, malnutrition remains an existing problem for Indonesia.

Desa Pagedangan is a small village located in the Pagedangan subdistrict, Tangerang Selatan. Desa Pagedangan has two Posyandu (Pos Layanan Terpadu), named Posyandu Seruni XI and Posyandu Seruni IX. Posyandu Seruni XI located at Jl Kampung Pagerhaur, behind the shophouse Foresta and opposite the Shell Pagedangan gas station. While Posyandu Seruni IX located at Jl. Kampung Tegal, behind Gramedia BSD (Figure 1.). 


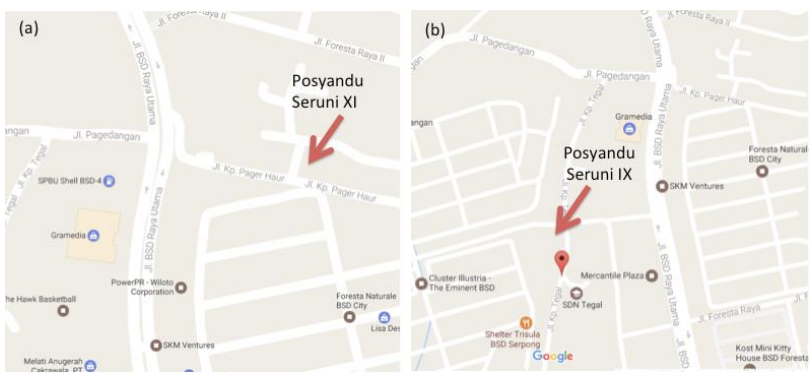

Figure 1. Location of Posyandu in Desa Pagedangan (a) Posyandu Seruni XI (b) Posyandu Seruni IX

Malnutrition can also be found in Desa Pagedangan. Economical dan educational background factors are the root causes of malnutrition in Desa Pagedangan. In 2016, Student Association of Food Technology (SAFT) from Food Technology Department of Swiss German University conducted a survey in Desa Pagedangan (Figure 2.) and it was recorded that $6.89 \%$ of children under five years old suffered from malnutrition case. 14 out of 18 respondents stated that their children were born with low birth weight.
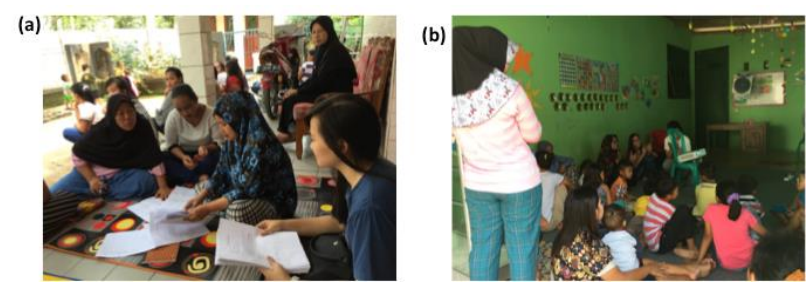

Figure 2. Survey and Interview Session in Desa Pagedangan (a) Posyandu Seruni XI (b) Posyandu Seruni IX

Mothers in Desa Pagedangan are in their mid to late-20s with their respective oldest children having the age of 3 to 5 years old. About half of the mothers work as housemaids or as factory workers, while the rest are housewives. As housemaids, the salary ranges between Rp. 650,000 ,- to $\mathrm{Rp}$. $750,000,-$ per month. Meanwhile, their husbands' occupations range from employees, security to factory workers. As security guards, the men earn around Rp. 300,000 per week. The average expenses for daily consumption are Rp. 45,000,- for each family of 3 to 6 people.
Most of the parents were married at young ages between 17 to 20 years old. Six out of 18 women were pregnant at an early age, which was under 20 years old. Actually, getting pregnant at a young age has a very high risk for the mother and fetus (Papri, et al., 2016). Most mothers in Desa Pagedangan are also not equipped with sufficient experience and knowledge to meet the nutritional requirement of their children.

The importance of exclusive breastfeeding and nutrition during pregnancy and early childhood are still overlooked by mothers. Based on the interview with the Kader of the posyandu, most of the mothers in Desa Pagedangan have not registered themselves at the Posyandu. This causes difficulties to monitor the condition of the development of infants because the provision of vitamins, immunizations, and weight weighing are only given to registered mothers and infants.

Local government assistance in the form of Makanan Pendamping Air Susu Ibu (MP-ASI) and supplementary foods for pregnant women is also considered to be insufficient. Biscuits were distributed every three months and each mother only received up to 3 biscuits. Seminars held by the local government and midwifery related to nutrition issues have been conducted, however, the participation was still low. Most of the mothers were unable to attend the seminars because of not having free time due to work or the baby was still too young and could not be left out. The rest preferred to stay at home and would attend the seminar only if there was a distribution of food or souvenirs.

In consequence, community service was conducted to increase nutritional awareness and fulfill the adequate amount of protein in daily basis. The community service covered seminars, cooking demo, and product development of healthy food. The seminar aimed to introduce the importance and benefit of healthy diet to parents and introduce the exclusive breastfeeding and MP-ASI for pregnant and lactating women, while cooking demo aimed to give ideas and encourage parents to prepare healthy diet with budget limitation. The formulation of rice porridge with overripe tempe was conducted aimed 
to fulfill the RDI of protein with preferable sensory acceptance.

\section{METHODS}

Some of the activities carried out in community service include: 1) Survey as a preliminary study in Desa Pagedangan; 2) Seminar about the importance of nutritious food consumption during pregnancy, lactation period and the importance of giving nutritious food for their children; 3) Introducing food ingredients as a source of nutrition followed by cooking demonstration activities and distribution of simple, inexpensive, yet nutritious recipe booklets; 4) Development and distribution of weaning food from overripe tempe to fulfill the RDI of protein with preferable sensory acceptance; and 5) Follow-up survey to evaluate the activities.

\section{Preliminary Study}

Preliminary study was conducted by distributing questionnaires to mothers in Posyandu Seruni IX and Posyandu Seruni XI, Desa Pagedangan, Tangerang Selatan. The aim of this survey was to identify the food preferences and eating habit of targeted society. Some of the questions included in the survey were age of their children, way of serving the food for their children (cooked or bought), food that were regularly given to their children and its frequency, and the average food expenses.

\section{Seminar and Cooking Demo}

The seminar and cooking demo were held in the same day (Table 1.) at Swiss German University (SGU). The speaker of the seminar was Maria Dewi Puspitasari Gunawan Puteri, S.T.P., M.Sc., Ph.D as a lecturer from Food Technology department of SGU. Forty mothers from Desa Pagedangan and Dadap were invited to this event and allowed to bring their children. Transports from respective living place (Desa Dadap \& Pagerhaur) to SGU campus were provided by committee. After the seminar and cooking demo, participants were given a feedback survey for evaluation.
Table 1. Rundown of the Seminar and Cooking

Demo Event

\begin{tabular}{ll}
\hline Time (WIB) & \multicolumn{1}{c}{ Activity } \\
\hline $08.00-08.30$ & $\begin{array}{l}\text { Pick up parents from Desa Pagerhaur and } \\
\text { Desa Dadap }\end{array}$ \\
$08.30-09.00$ & Re-registration and goodie bag distribution \\
$09.00-09.50$ & Seminar \\
$09.50-10.00$ & Break \\
$10.00-12.00$ & Cooking demo \\
$12.00-12.30$ & Closing photo session and lunch distribution \\
$12.30-13.00$ & $\begin{array}{l}\text { Transport parents back to Desa Pagerhaur } \\
\text { and Desa Dadap }\end{array}$ \\
\hline
\end{tabular}

\section{Development of Weaning Food}

The development of weaning food was conducted at Life Sciences and Technology Laboratory at Swiss German University, Tangerang.

\section{Materials}

Fresh tempe was acquired from a tempe merchant, which located in Pasar Modern BSD, Tangerang Selatan. Rice, oil, garlic powder, and other seasonings for the formulation were obtained from local supermarket Giant Alam Sutera, Tangerang, Indonesia.

Production of Overripe Tempe Powder and Overripe Tempe Extract

Overripe tempe was produced by using method from previous study (Hassanein et al., 2015; Gunawan-Puteri et al., 2015). To produce overripe tempe powder, the overripe tempe was thinly sliced and dried by oven drying for 6 hours at $60^{\circ} \mathrm{C}$ and then milled.

Three extracts that were compared in this formulation were: unchopped overripe tempe extract (UORTE), chopped overripe tempe extract (CORTE) and overripe tempe powder extract (ORTPE) or CORTE. The production of overripe tempe extracts were homogenized, heated at $100^{\circ} \mathrm{C}$ for 10 minutes and filtered (Gunawan-Puteri et al. 2018). 


\section{Formulation of Rice Porridge}

The overripe tempe powder and extract were then formulated into overripe tempe stock using previous research formulation (Setiadharma et al. 2015). Both of the overripe tempe powder and extract was then combined with oil and seasonings into overripe tempe stock with adjustment to fulfil 1/3 RDI of protein.

The formulation from overripe tempe powder consist of $30 \%$ overripe tempe powder, $29.5 \%$ caramel syrup, $26 \%$ salt, $5.5 \%$ sugar, and $4 \%$ of oil with dilution ratio 3:100 (Gunawan-Puteri et al. 2018). Ready-to-eat overripe tempe porridge was produced by cooking grounded uncooked rice and overripe tempe stock that were placed inside retortable aluminum pouch using pressure cooker. The rice was cooked in 6 variations of stock to rice ratio $(1: 3,1: 4,1: 5,1: 6,1: 7,1: 8, \mathrm{w} / \mathrm{v})$ and 3 variations of cooking time (10 $\mathrm{min}, 12 \mathrm{~min}$, and 15 $\mathrm{min}$ ). While the formulation from overripe tempe extract was also done in a sealed retort pouch and cooked in pressure cooker for certain time.

\section{Sensory Evaluation}

Each of the formula was evaluated by 10 trained panellists in a focus group discussion (FGD) and the best formula was then compared to selected commercial product and evaluated by mothers in Desa Pagedangan using 9-Scale Hedonic Test. The results were then examined statistically by Wilcoxon Test.

\section{7)}

\section{Protein Digestibility Analysis (Kristianti,}

The protein digestibility analysis was done by determining the soluble amino acid content of the sample. Both distilled water and phosphate buffer $\mathrm{pH} 8.0$ with the volume of $250 \mu \mathrm{L}$ each, were put into $250 \mu \mathrm{L}$ rice porridge extract. Then, it was incubated at $37^{\circ} \mathrm{C}$ for 5 minutes.

The reaction was stopped by adding $750 \mu \mathrm{L}$ $10 \%$ TCA. This was treated as the control. For the protein digestibility test, the steps were repeated but the distilled water was substituted with $250 \mu \mathrm{L} 4$ $\mathrm{mg} / \mathrm{ml}$ pancreatin enzyme solution. Both of the control and the solution with enzyme were centrifuged at 10,000 rpm for 10 minutes.
Afterwards, $300 \mu \mathrm{L}$ supernatant was taken and combined with $0.5 \mathrm{M} \mathrm{Na} \mathrm{CO}_{3}$ solution (1000 $\mu \mathrm{L})$ and Folin-Ciocalteu reagent $(200 \mu \mathrm{L}, 1: 2)$. Then, UV-Vis Spectrophotometer was used to read the absorbance of the samples at the wavelength of $578 \mathrm{~nm}$.

By using similar steps, tyrosine standard curve was also made by substituting the sample with various concentration of tyrosine solution. By interpolating to the curve, total soluble amino acid was determined. The protein digestibility was calculated as below:

(AA content enzyme treated - AA content enzyme untreated) / average protein content

DIIAS Calculation (FAO, 2013)

Indispensable amino acids and protein adequacy of infants were calculated by using DIAAS (Digestible Indispensable Amino Acid Score) calculation method. Digestible indispensable amino acid score, or DIAAS, is another method of measuring protein quality which refers to the capability of indispensable amino acids in meeting the human needs.

To determine the DIAAS for a food, there are two data that were required: the digestible indispensable amino acid (DIAA) content per gram of protein in food and the IAA reference ratio. Both were computed as below:

DIAA $=$ mg of IAA per gram protein of food $x$ true ileal digestibility coefficient for the same dietary indispensable amino acid*

*The true ileal digestible amino acid was obtained from mg AA per gram of food as consumed basis, per gram of food dry matter, or per gram of protein of food

IAA Reference Ratio = DIAA content in 1 gram protein of food $(\mathrm{mg}) / \mathrm{mg}$ of the same DIAA in 1 gram of reference protein following:

The DIAAS was calculated as the

DIAAS $(\%)=100 \times$ lowest value of digestible IAA reference ratio for a given AA scoring pattern 


\section{RESULTS AND DISCUSSION}

\section{Preliminary Study}

The preliminary study acquired 53 total responses from mothers in Desa Pagedangan with the infant age range of 1 month old up to 5 years old. However, based on the age, only 38 respondents who has infants above 6 months old and had already consumed weaning food.

The feeding frequency of weaning food based on the survey was showed on Table 2 . below. There were $58 \%$ respondents who gave weaning food three times a day. Meanwhile, only 5\% respondents who fed the weaning food once a day and the rest of total respondents gave weaning food twice a day.

Table 2. Feeding Frequency of Infants in Desa

$$
\text { Pagedangan }
$$

\begin{tabular}{cc}
\hline Weaning Food Feeding Frequency & Total Response (\%) \\
\hline Once a day & 5 \\
Twice a day & 37 \\
Three times a day & 58 \\
\hline
\end{tabular}

Respondents were asked to list 5 types of food that were regularly given to their children. The types of food are varying, for instance, steamed rice (nasi tim), commercial weaning porridge, vegetable and fruits, mung bean porridge, etc. Based on the responses (Figure 3.), most of the respondents $(39 \%)$ chose to give their children rice porridge as the first choice (major) weaning food, followed by steamed rice (nasi tim) and commercial weaning porridge $(21 \%)$.

Based on the survey, most of the respondents gave rice porridge to their children at 6 months old, followed by 8 months old and 9 months old (Figure 4.). Only few mothers who fed their children rice porridge below or above those ages. Mainly, rice porridge consumption stopped at the age of 12 months old. Nevertheless, there were some respondents who still gave their 3-years-old children rice porridge.

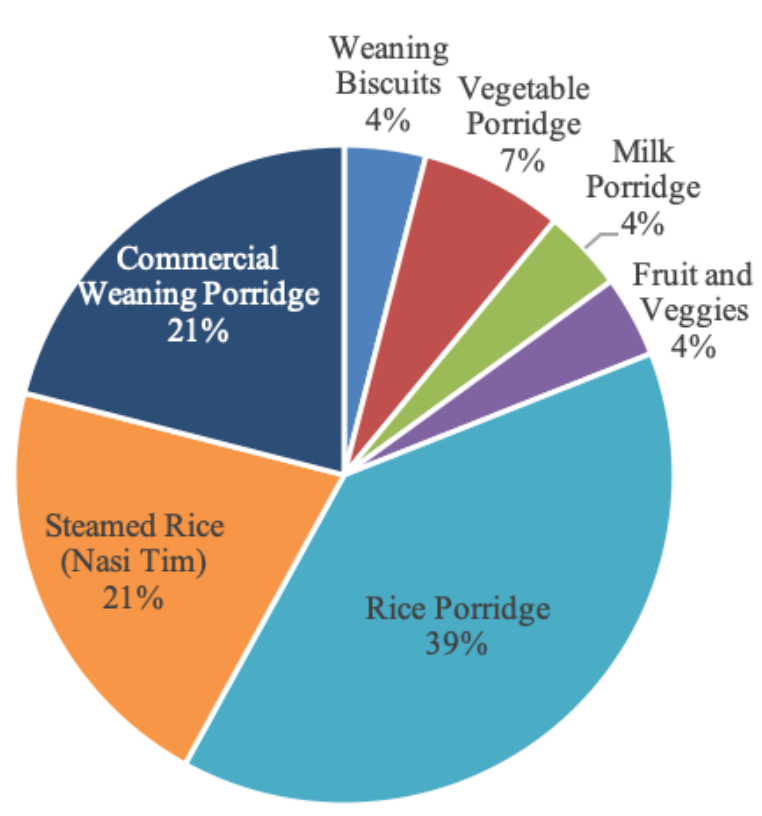

Figure 3. Preference of Weaning Food

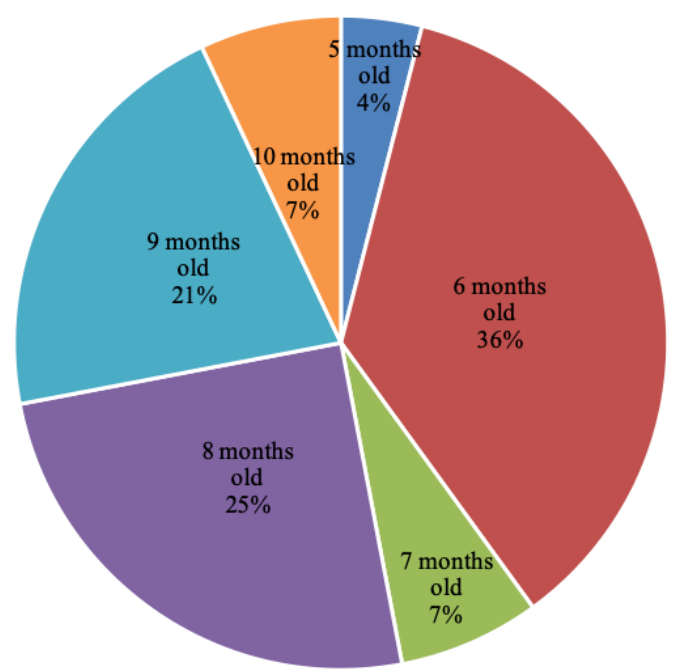

Figure 4. The Starting Age of Rice Porridge Consumption

According to the responses (Table 3.), 57\% mothers cooked weaning food while $43 \%$ bought the weaning food in the market or street vendors.

Table 3. Weaning Food Buying Habit

\begin{tabular}{cccc}
\hline & Cooking & Buying & Total \\
\hline Number of Respondents & $57 \%$ & $43 \%$ & $100 \%$ \\
\hline
\end{tabular}


While the average expenses for food consumption is about Rp. 45,000,- per family (up to 3 to 6 people) per day.

The respondents also showed high enthusiasm in improving their knowledge about healthy diet and cooking demo for giving them an idea to provide nutritious food. Therefore, seminar and cooking demo were also conducted afterwards.

\section{Seminar and Cooking Demo}

\section{Seminar}

The participants were arrived at SGU around 08.30 WIB (Figure 5.) and directly directed to the re-registration booth (Figure 6.). After they re-registered, they received a seminar kit including booklets of affordable recipes idea (Figure 6.). There were 30 participants who attended the seminar and cooking demo, they were allowed to bring their children throughout the events.
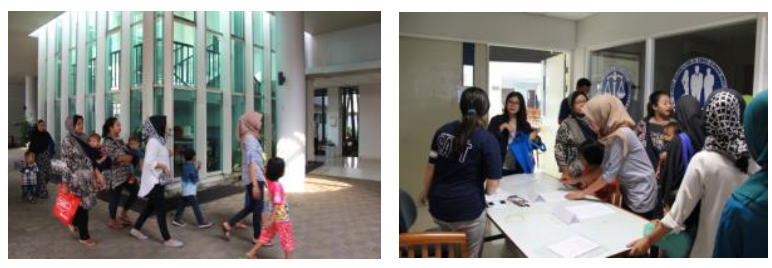

Figure 5. Arriving Participants and Re-Registration Process

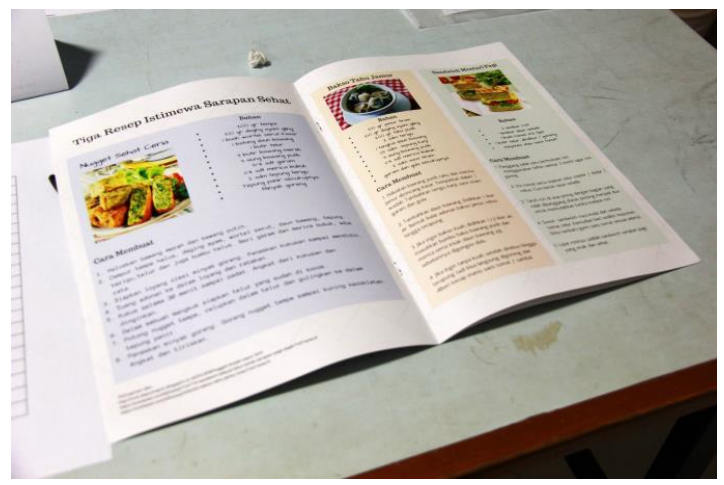

Figure 6. Free Booklets for Participants at Seminar and Cooking Demo Event

The seminar started at $09.00 \mathrm{WIB}$. The title of the seminar was "Memahami Pentingnya Sarapan \& Makanan Bergizi". The speaker was Maria
D.P.T. Gunawan Puteri as one of Food Technology Lecturer in Swiss German University.

There were two main topics delivered during the seminars, the first one was the importance of breakfast and nutritious diet and the second one was exclusive breastfeeding and weaning food for infants. On the first topic, the benefits of breakfast and the risks of missing breakfast were also elaborated and the practical and fast way to prepare breakfast were also discussed during the seminar (Figure 6.).
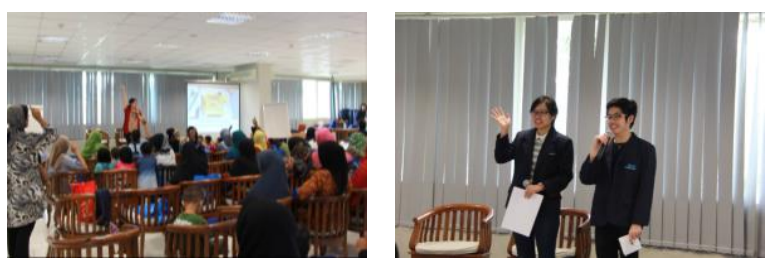

Figure 6. Interactive Seminar with Question and Answer Section

While the participant paid attention to the seminar (Figure 7.), their children were playing at the kids' corner provided by the committee (Figure 8.).

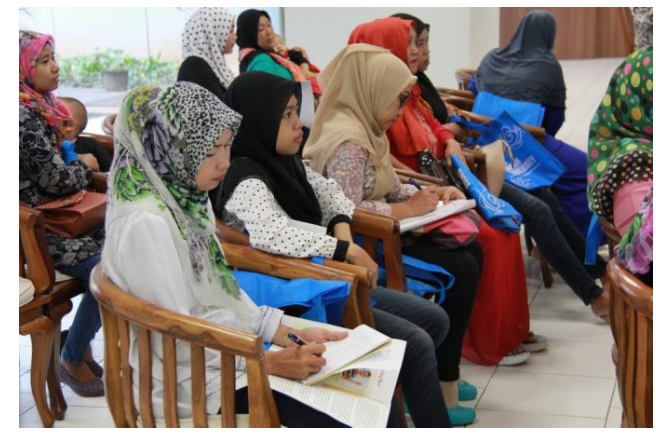

Figure 7. Participant Enthusiasm to the Seminar

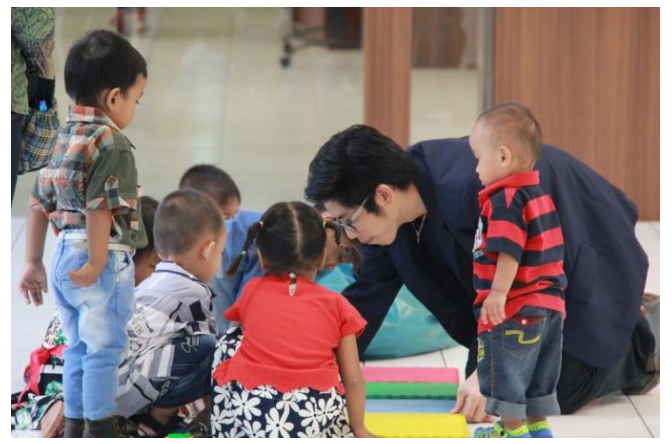

Figure 8. Children Playing at Kids' Corner

Kesehatan 
At the end of each section, the participants were allowed to ask some questions to the speaker (Figure 9.). Some of the questions from the participants were listed on Table 4.

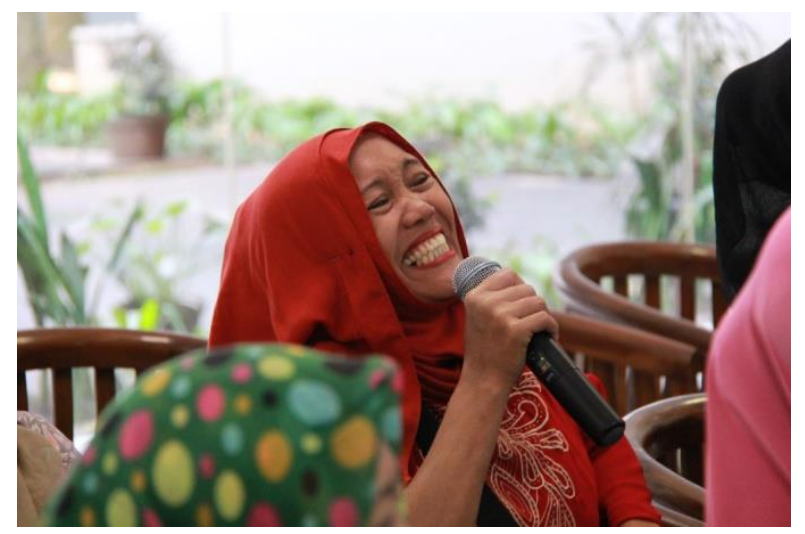

Figure 9. Question and Answer Section

Table 4. List of Questions from Participants

\begin{tabular}{|c|c|}
\hline Question & $\begin{array}{l}\text { Answer (From the } \\
\text { Speaker) }\end{array}$ \\
\hline $\begin{array}{l}\text { What if the children are picky } \\
\text { eaters? }\end{array}$ & $\begin{array}{l}\text { The goal is to } \\
\text { introduce food as } \\
\text { food to eat, not as } \\
\text { foreign object. } \\
\text { But do not scold } \\
\text { them if they do } \\
\text { not eat certain } \\
\text { types of food, } \\
\text { instead give them } \\
\text { challenge. } \\
\text { Various strategies } \\
\text { could be done to } \\
\text { do that, such as } \\
\text { give compliment } \\
\text { or rewards when } \\
\text { they succeed } \\
\text { eating healthy } \\
\text { food, for example } \\
\text { vegetables. }\end{array}$ \\
\hline $\begin{array}{l}\text { How about one of } \\
\text { participant's older child (high } \\
\text { school student) who is also a } \\
\text { picky eater? }\end{array}$ & $\begin{array}{l}\text { The parents have } \\
\text { to know the cause } \\
\text { why their child } \\
\text { does not want to } \\
\text { eat that food. For }\end{array}$ \\
\hline
\end{tabular}

Do elderly people need to eat vegetables?

instance, if the

child does not

like vegetables

because of the

texture (hard to

chew), the

vegetable can be

blended, cut,

crushed and

combined to

create healthier

menu, such as

blended vegetable

in omelette.

Of course, yes.

Instead, for

elderly (more

than 30 years

old), it is

suggested to eat

more fruits and

vegetables.

Because as the movement \& activity decrease, the digestive metabolism also decreases. One way to enhance the metabolism is to eat fiber.

At the end of the seminars, the participants acquired food ingredients from committee (Figure 10.).

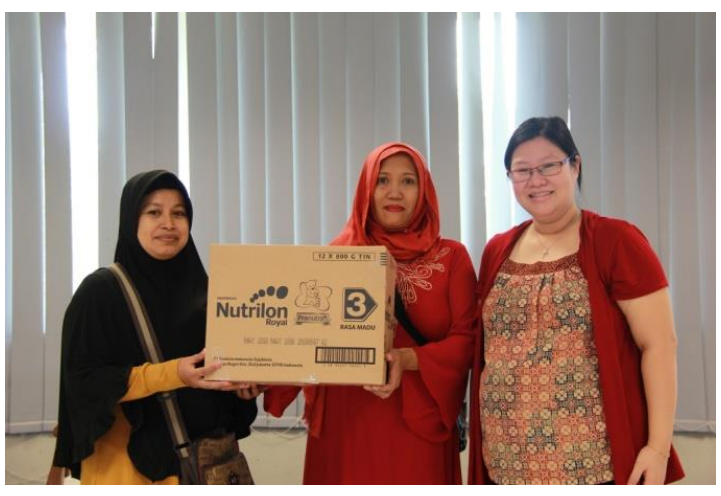

Figure 10. Appreciation Gift to Desa Pagedangan

Kesehatan 


\section{Cooking Demo}

Cooking demo is a way to introduce more to parents about the kind of foods that is good for children's breakfast and they way how to prepare and cook it. Cooking demo was held SGU Canteen and prepared by committee (Figure 11.).

Parents observed and heard explanation thoroughly about healthy breakfast options for kids and taste the food samples (Figure 12.). Examples of healthy, easy to make (or buy), and inexpensive breakfast are given through cooking demo.

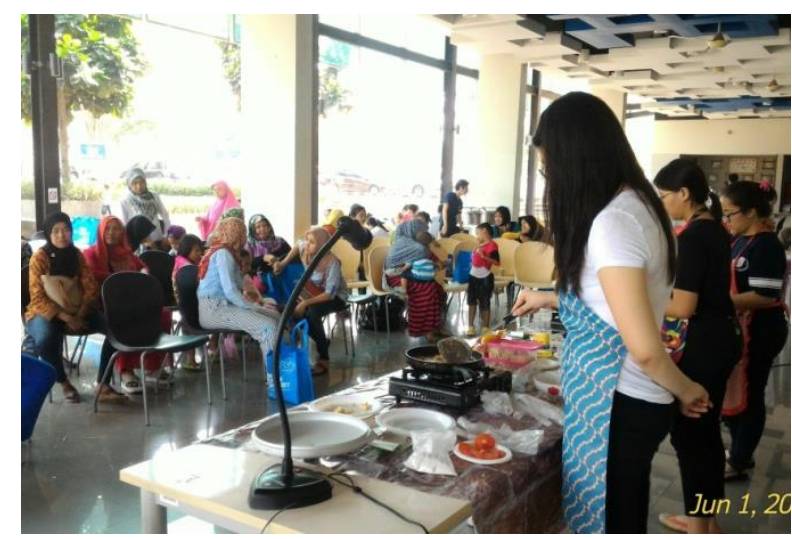

Figure 11. Live Cooking Demo

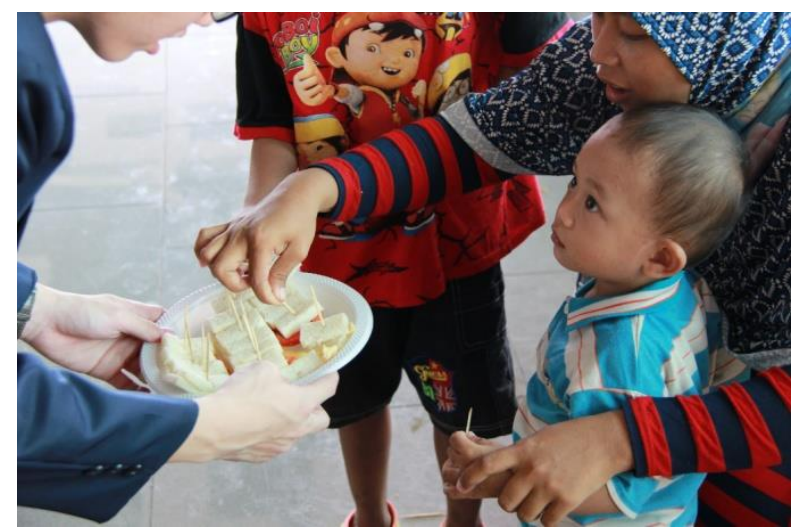

Figure 12. Food Tasting for the Participant

The main dishes showed in the demo were: 1) Vegetable nuggets ("Nugget Sehat Ceria"); 2) Tofu-and-Mushroom Meatball ("Bakso Tahu Jamur"); and 3) Sandwich ("Sandwich Mentari Pagi"). All the recipes can be found in the Booklet. And their favorite menu was Tofu-and-Mushroom Meatball (Figure 13.).
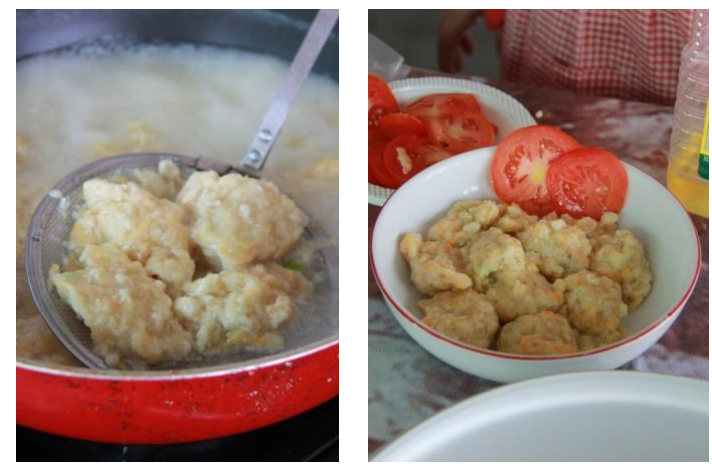

Figure 13. Favorite Menu at Cooking Demo

Afterwards, all the participant took a photo together (Figure 14.).

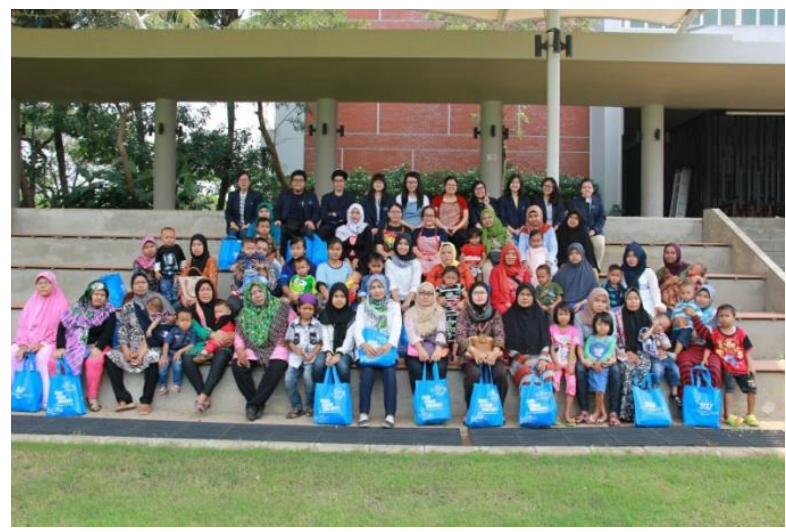

Figure 13. Photo Session with All Participants

\section{Feedback}

The participants were asked to fill a feedback questionnaire about the whole events (Figure 14.).

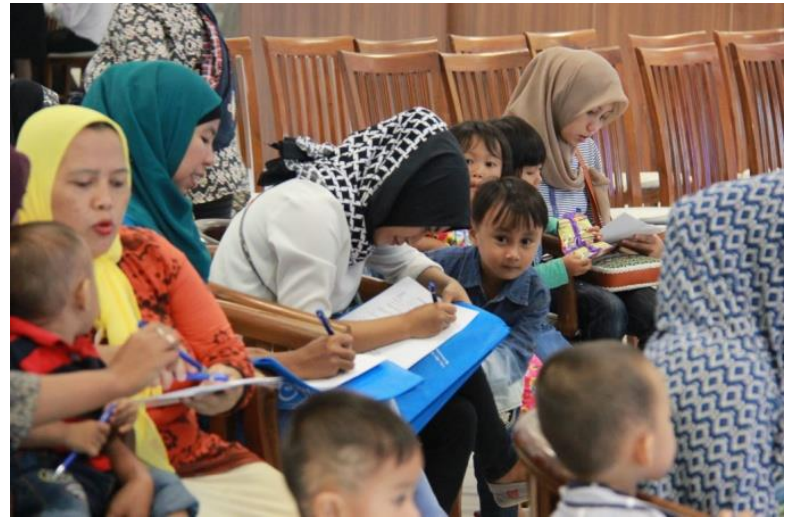

Figure 14. Participants Filling Questionnaires 
The responses of the whole event can be found at Table 5. 12 participants were from Desa Dadap while 18 respondents were from Desa Pagedangan.

Table 5. Feedback from the Participants

\begin{tabular}{|c|c|c|}
\hline Nama Kegiatan & $\begin{array}{l}\text { Pertanyaan yang } \\
\text { diajukan }\end{array}$ & Jawaban \\
\hline \multirow{11}{*}{$\begin{array}{l}\text { 1. Seminar untuk } \\
\text { memahami } \\
\text { pentingnya } \\
\text { sarapan dan } \\
\text { makanan bergizi }\end{array}$} & \multirow{2}{*}{$\begin{array}{l}\text { 1.1. Apakah kegiatan } \\
\text { yang dilakukan } \\
\text { berguna? }\end{array}$} & Ya $(100 \%)$ \\
\hline & & Tidak $(0 \%)$ \\
\hline & \multirow{4}{*}{$\begin{array}{l}\text { 1.2. Jika ada acara } \\
\text { bertema nutrisi, bentuk } \\
\text { acara apa yang anda } \\
\text { inginkan? }\end{array}$} & Seminar $(35 \%)$ \\
\hline & & Demo masak (67\%) \\
\hline & & Pameran $(0 \%)$ \\
\hline & & Lain-lain (0\%) \\
\hline & \multirow{5}{*}{$\begin{array}{l}\text { 1.3. Apakah ada } \\
\text { komentar mengenai } \\
\text { kegiatan ini? }\end{array}$} & $\begin{array}{l}\text { Saya sangat suka } \\
\text { dengan acara seperti } \\
\text { ini, karena sangat } \\
\text { bermanfaat bagi ibu- } \\
\text { ibu yang punya balita } \\
\text { dan mudah-mudahan } \\
\text { acara seperti ini } \\
\text { sering-sering diadakan } \\
\text { supaya ibu-ibu selalu } \\
\text { bisa menjaga nutrisi } \\
\text { dalam memberi } \\
\text { makanan untuk } \\
\text { keluarganya. }\end{array}$ \\
\hline & & $\begin{array}{l}\text { Seminar ini sangat } \\
\text { bagus, saya sebagai } \\
\text { seorang remaja jadi } \\
\text { mengetahui } \\
\text { pentingnya sarapan, }\end{array}$ \\
\hline & & $\begin{array}{l}\text { Acara hari ini sudah } \\
\text { bagus dan sangat } \\
\text { bermanfaat, untuk } \\
\text { lebih ditingkatkan, } \\
\text { perlu ada tanya jawab } \\
\text { masalah gizi }\end{array}$ \\
\hline & & $\begin{array}{l}\text { Terima kasih ilmunya } \\
\text { yang telah diberikan, } \\
\text { mudah-mudahan } \\
\text { bermanfaat untuk } \\
\text { saya. }\end{array}$ \\
\hline & & $\begin{array}{l}\text { Bagi kami sangat } \\
\text { bermanfaat untuk bisa } \\
\text { memenuhi gizi anak- } \\
\text { anak/keluarga dan } \\
\text { mudah-mudahan untuk } \\
\text { tahun kedepannya bisa } \\
\text { lebih baik lagi. Terima } \\
\text { kasih atas } \\
\text { undangannya dan } \\
\text { hidangannya }\end{array}$ \\
\hline \multirow{3}{*}{$\begin{array}{l}\text { 2. Seminar untuk } \\
\text { perkenalan } \\
\text { program ASI- } \\
\text { ekslusif dan MP- } \\
\text { ASI yang sehat }\end{array}$} & \multirow{2}{*}{$\begin{array}{l}\text { 1.1. Apakah kegiatan } \\
\text { yang dilakukan } \\
\text { berguna? }\end{array}$} & Ya $(100 \%)$ \\
\hline & & Tidak $(0 \%)$ \\
\hline & 1.2. Jika ada acara & Seminar $(26 \%)$ \\
\hline
\end{tabular}

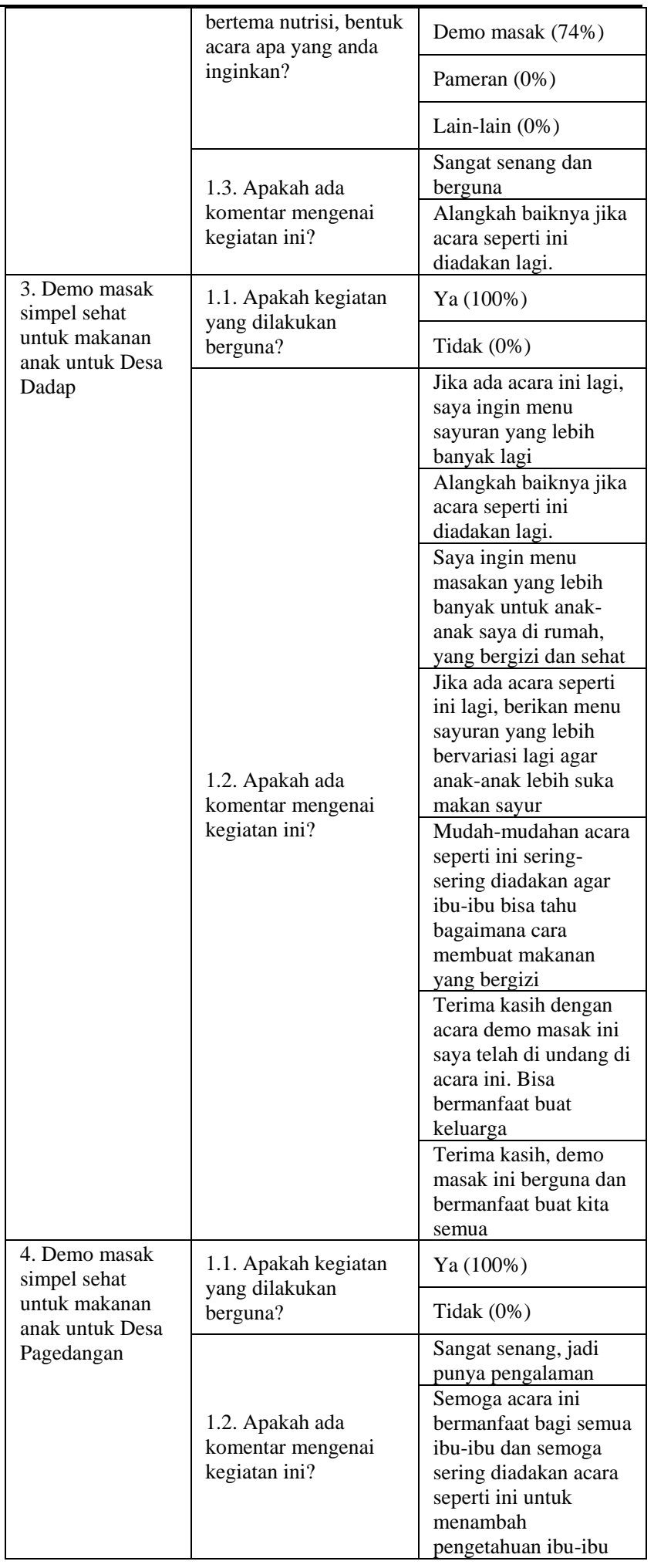

Kesehatan 


\section{Development of Weaning Food}

The formulation of rice porridge from both overripe tempe powder and extract were initiated by determining the amount of overripe stock and cooking time used to make the rice based. The desirable ratio was 1:5 with 12 minutes of cooking time where the results showed the best texture and appearance for rice porridge.

\section{Formulation of Rice Porridge from} Overripe Tempe Powder

The formulation combined uncooked rice, overripe tempe powder, salt and other seasoning, palm oil or garlic oil also water in a sealed aluminum pouch (Figure 15.) and cooked with pressure cooker. The best formula based on Fortunata (2017) was the formula with garlic oil with the mean score for hedonic test $4.43 \pm 1.57^{\mathrm{a}}$ out of 9.00 whereas the commercial product had a mean score of $4.10 \pm 1.37^{\mathrm{b}}$.

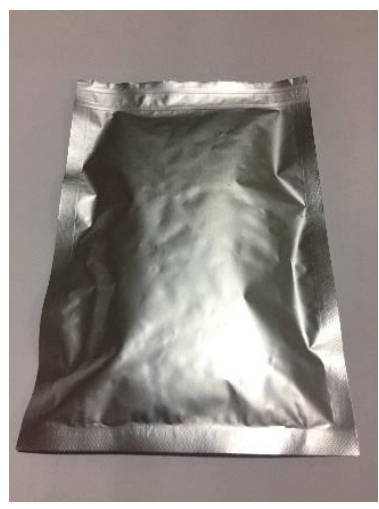

Figure 15. Formulated Porridge in Sealed Aluminum Pouch

The selected formula contains $6.23 \%$ of total nitrogen and therefore $200 \mathrm{~g}$ portion of the porridge was able to contribute to $48 \%$ and $36 \%$ RDI of protein of 1-3years old and 4-6 years old toddler. However, the fiber content was still considered high and too much dietary fiber consumption during infancy may lead to insufficient calorie and nutritional intakes because dietary fiber contributes to satiety effect (Bhatia, 2004). Therefore, the extraction of overripe tempe powder was then conducted and formulated.

\section{Formulation of Rice Porridge from Overripe Tempe Extract}

Based on Christli (2018), the selected overripe tempe extract was CORTE because it contained more total and indispensable amino acids and required 7 times less production time and processing steps compared to ORTPE. Though CORTE has slightly lower protein content and higher dietary fiber content (Table 6.).

Table 6. Protein and Dietary Fiber Content of

Overripe Tempe Extract

\begin{tabular}{ccc}
\hline Parameter & $\begin{array}{c}\text { Protein }(\mathrm{g} / \\
\text { 100 g ORT) }\end{array}$ & $\begin{array}{c}\text { Dietary Fiber }(\mathrm{g} / \\
\mathbf{1 0 0} \text { g ORT) }\end{array}$ \\
\hline UORTE & 0.95 & 4.06 \\
CORTE & 4.13 & 10.08 \\
ORTPE & 4.61 & 8.36 \\
\hline
\end{tabular}

The dietary fiber was then reduced by using vacuum filtration and concentrated to reach the minimum SNI protein standard $(2 \mathrm{~g} / 100 \mathrm{kcal})$. However, the result was too intense bitter taste. The focus group discussion managed to find the maximum concentration for the CORTE in order to perceived favorable taste, however the amount of protein was still too low. Therefore, it was concluded that CORTE cannot be used as a single protein source. The isolated soy protein and skimmed milk powder were chosen as additional protein source and both of them has inexpensive price.

The final formula obtained by combining all ingredients was then evaluated by 30 mothers in Desa Pagedangan, Tangerang Selatan, Indonesia. Based on the result, the mean value was $6.47 \pm 0.73$ for overall acceptance by hedonic taste. The selected formula had protein content of $2.8 \mathrm{~g} / 100$ $\mathrm{kcal}$ and able to fulfill 4.5/18 RDI of protein per serving for $7-11$ months old infants. 


\section{Indispensable Amino Acid Adequacy Estimation and Protein Digestibility}

The DIAAS score of rice porridge is $57 \%$ for infants age group of 6 months old and $61 \%$ for infants age group of 1 up to 2 years old. Nevertheless, the Ministry of Health of the Republic of Indonesia suggested that infants have to consume breastmilk 2 times in a day. The DIAAS score of breastmilk is $684 \%$ and $760 \%$ respectively for infants 6 months old and $1-2$ years old.

Protein digestibility was done by determining the soluble amino acid content in the sample. Both of formulated porridge and commercial product were compared, the results of protein digestibility ratio were 5.13 and 3.48 in sequence. The higher ratio was indicated better digestibility.

\section{CONCLUSION}

From this community service and throughout the whole activities, the enthusiasm of mothers from Desa Pagedangan can be perceived as they committed to participate in different activities such as seminars, cooking demo, and product development.

The results showed both cooking demo and seminars were giving beneficial contribution for participant (100\% were agree) and the feedback was really helpful to improve our contributions in the upcoming future. The formulation of rice porridge with overripe tempe extract was also able to fulfill 4.5/18 RDI of protein of infants $7-11$ months old. The final product showed better sensory acceptance than commercial product with mean value $6.47 \pm 0.73$ for overall acceptance by hedonic taste. Other than that, the formulated porridge has better protein digestibility and inexpensive cost which was IDR 869.

It is hoped that throughout this event, mothers from Desa Pagedangan will be able to notice their children's nutritional needs and the shared knowledge will be beneficial to remind them of the importance of a healthy diet for their family.

\section{ACKNOWLEDGEMENT}

The product development project was supported by a grant from the Directorate General of Resources for Science, Technology and Higher Education of the Republich Indonesia with contract number SP DIPA-042.06.1.4015 16/2017, 6 December 2016 and 0789/K4/KM/2018.

Authors also express their gratitude to the children and families from Desa Pagedangan, Tangerang Selatan, Indonesia, who participated in our projects.

\section{REFERENCES}

Badan Penelitian dan Pengembangan Kesehatan Kementerian Kesehatan RI. (2016). Laporan Hasil RisetKesehatan Dasar (Riskesdas) Indonesia tahun 2016. Jakarta, Indonesia: CV Kiat Nusa.

Bhatia J. (2004). Perinatal Nutrition: Optimizing Infant Health and Development. Florida: CRC Press.

Christli, L. (2018). Development of Rice Porridge with Overripe Tempeh Extract for Infants. B.Eng. diss., Swiss German University.

FAO. (2013). Dietary protein quality evaluation in human nutrition, Rome: FAO Expert Consultation Report.

Fortunata, S.A. (2017). Formulation of Overripe Tempe in Weaning Food Based on Sensory Acceptance. B.Eng. diss., Swiss German University.

Gunawan-Puteri, M. D. P. T., Hassanein, T. R., Prabawati, E. K., Wijaya, C. H. and Mutukumira, A. N. (2015). Sensory characteristics of seasoning powders from overripe tempeh, a solid state fermented soybean. Procedia Chemistry, 14: 263-269.

Gunawan-Puteri, M. D. P. T., Christli, L., Prabawati, E. K., \& Marpaung, A. M. (2018). Development of Rice Porridge with Overripe Tempeh Extract for Infants. Proceedings of the 
International Conference on Food, Agriculture and Natural Resources (FANRes 2018), 172: 188-193.

Gunawan-Puteri, M. D. P.T., Fortunata, S. A., Prabawati, E. K., Kristianti F., and Wijaya, C. H. (2018). Overripe Tempe as Source of Protein in Development of Ready to Eat Porridge. International Food Research Journal, 25 (Suppl. 2): S201 - S2019.

Hassanein, T. R., Prabawati, E. K. and Gunawan-Puteri, M. D. P. T. (2015). Analysis of Chemical and Microbial Change During Storage of Overripe Tempeh Powder as Seasoning Material. International Journal of Science and Engineering, 8(2): 131-134.

Kristianti, F. (2017). Impact of GDL Acidification towards Nutrient Properties of Tempe and Overripe Tempe. B.Eng. diss., Swiss German University.
Papri, F. S., Khanam, Z., Ara, S., \& Panna, M. B. (2016). Adolescent Pregnancy: Risk Factors, Outcome and Prevention. Chattagram Maa-OShishu Hospital Medical College Journal, 15(1): 53 $-56$.

Setiadharma, B., Kartawiria, I. S. and Gunawan-puteri, M. D. P. T. (2015). Development of Instant Stock Cube from Overripe Tempeh. Proceeding of International Conference on Innovation, Entrepreneurship and Technology, 211-213. Tangerang: Swiss German University. 